Przegląd Prawa Konstytucyjnego

-ISSN 2082-1212-

DOI 10.15804/ppk.2016.05.17

$-\mathrm{Nr} 5(33) / 2016$

\title{
Recenzja
}

\section{Leges ab omnibus intellegi debent. Księga XV-lecia Rządowego Centrum Legislacji, red. Wojciech Brzozowski, Adam Krzywoń, Wydawnictwo Sejmowe, ISBN: 978-83-7666-401-9, Warszawa 2015, ss. 466}

Z satysfakcją należy odnotować fakt, iż literatura prawnicza wzbogaciła się o kolejną cenną pozycję. Odwołanie się przez Autorów w tytule dzieła do łacińskiej paremii Leges ab omni intellegi debunt (Prawa powinny być rozumiane przez wszystkich) wskazuje rzeczywisty cel starań licznych legislatorów, którymi są pracownicy Rządowego Centrum Legislacji - państwowej jednostki organizacyjnej podległej prezesowi Rady Ministrów, zapewniającej koordynację działalności legislacyjnej Rządu, prezesa Rady Ministrów i innych organów administracji rządowej, a także obsługę prawną Rady Ministrów. Temu to właśnie organowi, w XV - lecie działalności, poświęcona została wspomniana księga, której Autorami poszczególnych fragmentów są znakomici dogmatycy i teoretycy prawa. Podjęcie trudu ukazania pozycji faktycznej i prawnej tego organu zasługuje ze wszech miar na pozytywną ocenę, należy bowiem mieć na uwadze fakt, iż począwszy od dokonanej 23 stycznia 2009 r. nowelizacji ustawy z 8 sierpnia 1996 r. o Radzie Ministrów, RCL z podmiotu przygotowującego stanowiska prawno - legislacyjne w stosunku do propozycji przedkładanych przez poszczególnych członków Rządu, przekształciło się w organ opracowujący rządowe projekty ustaw, co doprowadziło do likwidacji - krytykowanego od lat -,, resortowego” systemu tworzenia prawa. 
Księga została podzielona na cztery części. W pierwszej, zatytułowanej,„Rządowe Centrum Legislacji - wczoraj i dziś” znajdują się trzy opracowania ukazujące ewolucję funkcji i zadań RLC w latach 2000-2015 (Autorem jest były prezes Centrum Maciej Berek), przebieg prac legislacyjnych, w wyniku których powstało Centrum (Autor: Piotr Gryska) oraz model aplikacji legislacyjnej (Autor: Sławomira Wronkowska).

W pierwszym merytorycznym opracowaniu księgi Maciej Berek dokonuje analizy poszczególnych zadań wykonywanych przez RCL, obrazuje ich przeobrażenia oraz sposoby realizacji przyznanych organowi kompetencji. $\mathrm{Na}$ wstępie przypomina genezę utworzenia Centrum, którą stanowił art. 8 pkt 2 ustawy z 24 lipca 1999 r. o zmianie ustawy o działach administracji rządowej oraz niektórych innych ustaw. Na mocy tego przepisu w ustawie z 8 sierpnia 1996 r. o organizacji i trybie prac Rady Ministrów oraz o zakresie działania ministrów, dodano art. 14a-i, które do dziś określają formę prawną, zakres działania i organizację Centrum. Przypomniane zostały także szczegółowe zadania RCL w myśl regulacji pierwotnych oraz według stanu prawnego na dzień 1 stycznia $2015 \mathrm{r}$.

Powyższemu opracowaniu należy poświęcić szczególną uwagę, jako że stanowi ono wręcz sedno księgi, ukazując nie tylko rozwiązania prawne dotyczące Centrum lecz także praktyczną stroną realizowanych zadań. Nie jest także wolne - co należy ocenić wyjątkowo pozytywnie - od uwag dotyczących obowiązujących rozwiązań prawnych. Autor w sposób zwięzły, aczkolwiek bardzo rzetelny zobrazował realizację przez RCL następujących zadań: 1) koordynację działalności legislacyjnej Rady Ministrów, prezesa RM i innych organów administracji rządowej, 2) opracowywanie opinii prawno - legislacyjnych do każdego projektu rządowego aktu normatywnego, 3) opracowywanie rządowych projektów ustaw, 4) wykonywanie orzeczeń Trybunału Konstytucyjnego, 5) partycypację w planowaniu działalności legislacyjnej Rady Ministrów, 6) publikację prawa (chodzi o wydawanie przez prezesa RM Dziennika Ustaw oraz Dziennika Urzędowego RP,,Monitor Polski”), 7) prowadzenie portali informacyjnych (chodzi o serwis Rządowy Proces Legislacyjny oraz Publiczny Portal Informacji o Prawie), 8) inne zadania (m.in. wpływ na ewentualne skierowanie każdego rządowego projektu aktu normatywnego do Rady Legislacyjnej przy prezesie RM w celu uzyskania opinii, obowiązek uczestniczenia przedstawiciela RCL (w randze 
prezesa lub wiceprezesa) w posiedzeniach wszystkich komitetów Rady Ministrów, prowadzenie szkoleń dla legislatorów pracujących w strukturach administracji rządowej oraz parlamentarnych).

Nie dokonując szczegółowej analizy treści omówień Autora, charakteryzujących poszczególne zadania Centrum, warto przytoczyć jednak niektóre bardzo trafne jego spostrzeżenia. Np. omawiając funkcję koordynacyjną zauważa, że pomimo iż celem kreacji RLC było wzmocnienie prezesa RM przez podporządkowane mu Centrum, które ma koordynować wszelkie prace legislacyjne prowadzone przez Rząd, to jednak ani przepisy dotyczące RCL, które weszły w życie 1 stycznia 2000 r., ani też te, które obowiązują obecnie, nie wyposażają Centrum w narzędzia władczego oddziaływania o charakterze koordynacyjnym. Co prawda, kolejne wprowadzane w tym obszarze zmiany wzmacniają rolę tego organu, ale nadal katalog jego uprawnień nie jest całkowicie adekwatny do ustawowo przypisanej funkcji. Konstatacja o nieadekwatnym do zasadniczego celu wyposażeniu RCL w narzędzie koordynacyjne jest - zdaniem Autora - tym bardziej znamienna, że przypisanie Centrum tej zasadniczej funkcji wydaje się być uzasadnione faktem, iż RCL jest jednostką organizacyjną podporządkowaną bezpośrednio prezesowi RM, którego pozycja w aktualnym porządku ustrojowym uległa wyraźnemu wzmocnieniu (s. 15). Z kolei, omawiając opinie prawno - legislacyjne przedstawiane przez RCL do każdego projektu rządowego aktu normatywnego podkreśla, że pomimo, iż opinie te nie mają charakteru wiążącego, to praktyka, znajdująca uzasadnienie w przepisach Regulaminu Rady Ministrów, wskazuje w zasadzie na rozstrzygające stanowisko RCL w zakresie dotyczącym zagadnień legislacyjnych. Wynika to przede wszystkim z siły autorytetu zbudowanego przez RCL jako instytucję oraz przez pracowników RCL (s. 17). Wrażenie robi zestawienie statystyczne obrazujące skalę zadania Centrum sprowadzającego się do wyrażania opinii prawno-legislacyjnych: w 2010 r. - 3216, w 2011 r. - 3121, w 2012 r. - 3137, w 2013 r. - 3154, w 2014 r. - 3817 (s. 16, przypis 9). Z kolei, z analizy - nowej od 2009 r. - kompetencji RCL, polegającej na sporządzaniu projektów ustaw dowiadujemy się, że do końca 2014 r. Centrum opracowało na podstawie założeń przedłożonych przez ministrów 111 projektów ustaw. Autor wyjaśnia, że jest to liczba znacznie mniejsza od ogólnej liczby projektów ustaw przyjętych przez Radę Ministrów, należy jednak uwzględnić, że nie w każdym przypadku sporzą- 
dzenie projektu ustawy poprzedzone jest opracowaniem i przyjęciem przez Radę Ministrów projektów założeń (s. 21).

W drugim opracowaniu pierwszej części księgi Piotr Gryska dokonał wnikliwej analizy przebiegu prac legislacyjnych, w wyniku których powstało RCL. Przegląd treści opracowania pozwala na zapoznanie się $\mathrm{z}$ argumentami podnoszonymi w trakcie dyskusji parlamentarnej i zastrzeżeniami, jakie były zgłaszane do uregulowań zmierzających do wyodrębnienia RCL za struktur Kancelarii Prezesa Rady Ministrów. Skłania również do weryfikacji obaw przedstawianych przez przeciwników powstania RCL lub głosów podważających poszczególne elementy konstrukcji jego wyodrębnienia (np. s. 35-36, 42,50 ). Autor przypomniał, że punktem wyjścia propozycji zmiany procedury wewnętrznego postępowania w ramach administracji rządowej i stworzenia Centrum Legislacyjnego Rządu (taką nazwę początkowo postulował projekt rządowy) jako aparatu obsługującego premiera, Radę Ministrów i stałe komitety Rady Ministrów w realizacji zadań legislacyjnych było stwierdzenie, że ówczesny sposób ich realizacji nie był odpowiednio wydajny i nie gwarantował wymaganego wysokiego poziomu. Zarówno bowiem Departament Legislacyjny KPRM, jak i departamenty prawne poszczególnych ministerstw były niewystarczające dla realizacji ogromu prac legislacyjnych. Zwracano również uwagę, że o konieczności stworzenia fachowego i sprawnego ośrodka legislacyjnego przesądza obowiązek dostosowania prawa do norm konstytucji nałożony na Radę Ministrów przez przepisy rozdziału XIII ustawy zasadniczej, a także pilna konieczność przeglądu i dostosowania prawa polskiego w związku z integracją z Unią Europejską (s. 31).

Rozdział I wieńczy opracowanie Sławomiry Wronkowskiej na temat aplikacji legislacyjnej. Autorka podkreśla, że idea takiej aplikacji zrodziła się $\mathrm{z}$ pilnych potrzeb wynikłych $\mathrm{z}$ dokonującej się transformacji ustrojowej wymagającej głębokiej zmiany prawa obejmującej cały jego system. Aby temu zadaniu sprostać, potrzebni byli liczni, dobrze wykształceni i doświadczeni prawnicy, w tym także biegli w sztuce legislacyjnej (s. 44). Sedno opracowania, traktujące o aplikacji legislacyjnej, Autorka poprzedziła ściśle związanymi z tematem rozważaniami, z których dowiadujemy się m.in. a) jaka była przyczyna w początkowym okresie transformacji - zmniejszenia się liczby legislatorów, b) jakie przyczyny spowodowały konieczność wzmocnienia legislacyjnych służb parlamentarnych oraz tworzenia zaplecza eksperckiego, 
c) jakie są rzeczywiste zadania legislatorów, d) jaki wpływ miał tzw. kryzys legislacji lat 70., który uwidocznił się w bardzo wielu państwach, na rozwój nauki o tworzeniu prawa oraz powstawaniu różnego rodzaju organizacji zrzeszających osoby zainteresowane tworzeniem prawa (s. 54-57). Z kolei, odnosząc się stricte do aplikacji legislacyjnej Autorka przypomniała, że decyzja akceptująca kształcenie legislatorów w formie aplikacji została podjęta przez ministra Jana Rokitę - Szefa Urzędu Rady Ministrów 1 września 1993 r. Założenia programowe i organizacyjne aplikacji zostały przygotowane przez Autorkę opracowania, a następnie przyjęte przez Zespół Ekspertów do Spraw Prawa i Legislacji przy prezesie Rady Ministrów. Do 2009 r. aplikacja była prowadzona najpierw przez Urząd Rady Ministrów, a następnie przez Kancelarię Prezesa Rady Ministrów. W lutym 2009 r. aplikację przejęło Rządowe Centrum Legislacji (s. 58). W dalszej części opracowania Autorka omawia podstawy prawne odbywanej legislacji, źródła finansowania, założenia i programy aplikacji, sposoby naboru kandydatów, wymienia osoby prowadzące aplikację i formę przeprowadzania egzaminów (s. 59-61). Część rozważań ma charakter wręcz kronikarski, gdyż Autorka wymienia z imienia i nazwiska zarówno osoby które doprowadziły do zbudowania aplikacji jak te, które prowadziły zajęcia $\mathrm{z}$ aplikantami.

W drugiej części księgi, której nadano tytuł Rządowy proces legislacyjny perspektywa porównawcza zawarto opracowania przedstawiające rozwiązania instytucjonalne i organizacyjne stosowane w wybranych krajach Unii Europejskiej, służące zapewnieniu prawidłowego toku postępowania legislacyjnego. Z informacji przekazanej przez redaktorów tomu (s. 10) wynika, że stanowią one pokłosie zorganizowanej przez RCL 27 lutego 2015 r. w Kancelarii Prezesa Rady Ministrów konferencji pt.,,15 lat funkcjonowania modelu rządowego procesu legislacyjnego - perspektywa porównawcza”. Część tę otwiera artykuł Roberta Grzeszczaka traktujący o modelu procesu legislacyjnego w Unii Europejskiej. Pozostałych sześć opracowań dotyczy analizy modelu rządowego procesu legislacyjnego w RFN (Grzegorz Wierczyński), Czechach (Jarosław Sułkowski) i Hiszpanii (Marta Kłopocka-Jasińska), modelu procesu legislacyjnego w Austrii (Szymon Pawłowski) i we Francji (Anna Chmielarz-Grochal) oraz modelu procesu legislacyjnego w parlamencie Zjednoczonego Królestwa Wielkiej Brytanii i Irlandii Północnej (w zakresie rządowych projektów ustaw) - autor Anna Michalak. Należy 
przyznać, że treść powyższych opracowań wyśmienicie wkomponowuje się w zasadniczy nurt Księgi, dając możliwość porównania istniejących w Europie rozwiązań, a ponadto skłania do zastanowienia, czy istniejący w Polsce kształt rządowego procesu legislacyjnego osiągnął optymalny poziom, czy nie należałoby dodatkowo skorzystać $\mathrm{z}$ instrumentów przewidzianych $\mathrm{w}$ innych europejskich porządkach prawnych.

Trzecia część Księgi nosi tytuł Dylematy legislacyjne różnych gałęzi prawa i dyscyplin prawniczych. Zawiera ona następujące opracowania: Wybór reżimu penalnego - odpowiedzialność karna a inne formy odpowiedzialności (Sławomir Żółtek), Wybrane zagadnienia legislacyjne prawa rodzinnego (Maciej Domański), Problemy legislacyjne w prawie pracy (Marta Madej-Kaleta), Dylematy legislacyjne prawa wyznaniowego (Wojciech Brzozowski), Perspektywy unifikacji postępowania administracyjnego (Agnieszka Krawczyk), Stanowienie prawa karnego procesowego (Łukasz Chojniak), Zagadnienia legislacyjne w pracach nad przyszłym kodeksem postępowania karnego (Krystian Markiewicz). Zasygnalizowanie choćby bardzo skrótowo części problemów podniesionych przez wymienionych wyżej autorów nie jest możliwe. Wypada zatem odwołać się ponownie do słów redaktorów tomu, którzy charakteryzując tematykę trzeciej części Księgi stwierdzili: „Jest [...] oczywiste, że reguły rządzące daną gałęzią lub dyscypliną wymagają przyjęcia przez legislatora odpowiedniej optyki - dostrzegania, iż w poszczególnych obszarach, m.in. ze względu na charakter regulowanych stosunków społecznych lub założenia systemowe, prawo „pisze się inaczej” (s. 10).

Ostatnia, czwarta część Księgi nosi tytuł Wokół zagadnień stanowienia prawa i zawiera opracowania dotyczące szerokiego spektrum zagadnień legislacyjnych, wychodzących często poza problematykę związaną z działaniami RCL, a ich autorami są wybitni teoretycy i dogmatycy prawa. Ponieważ dokonanie choćby krótkiej charakterystyki szczegółowej analizy poruszonych zagadnień nie wchodzi w grę (ta część Księgi liczy jedenaście opracowań), wypada chociaż zasygnalizować sformułowane tematy, które m.in. koncentrują się na tematyce legislacyjnej, kwestiach polskiego trybu ustawodawczego jak i orzeczniczej działalności Trybunału Konstytucyjnego: Ryszard Piotrowski, Ustrojowe konsekwencje inflacji prawa, Krzysztof Kaleta, Artur Kotowski, Kodowanie a dekodowanie znaczenia prawnego - zarys dyskursywnego modelu tworzenia prawa, Jarosław Szymanek, Udział czynnika 
eksperckiego w procesie ustawodawczym, Paweł Skuczyński, Etyka legislatora a racjonalne tworzenie prawa, Marzena Laskowska, Notyfikacja przepisów technicznych jako element postępowania ustawodawczego - aspekty konstytucyjne, Sławomir Patyra, Tryb pilny w sejmowym postępowaniu ustawodawczym - reguła czy wyjątek?, Adam Krzywoń, Badanie przez Trybunał Konstytucyjny trybu ustawodawczego - uwagi w sprawie dopuszczalności działania ex officio, Marek Zubik, O jeden dzień za długo... Konstytucyjne ramy wyznaczania daty głosowania w wyborach, Kamila Doktór-Bindas, Jan Podkowik, Ograniczenia konstytucyjnych wolności i praw a pozakonstytucyjne akty normatywne, Piotr Bogdanowicz, Skutki stwierdzenia nieważności dyrektywy zperspektywy prawa (prawodawcy) krajowego, Marcin Wiącek, Skutki stwierdzenia nieważności przepisów nowelizujących.

Inicjatorom wydania Księgi należy wyrazić wdzięczność i podziw, zaś jej merytoryczną treść ocenić bardzo wysoko. Stanowi ona wyraz uznania i uhonorowania dla licznej rzeszy legislatorów (nie tylko pracowników RLC), osób dysponujących wyśmienitą znajomością procedury oraz zasad techniki prawodawczej, bez pracy których niemożliwe byłoby realizowanie przez państwo funkcji prawotwórczej, a jednocześnie pozostających w cieniu toczącego się procesu legislacyjnego. O szacunku, jakim są darzeni w środowisku prawniczym, świadczy sama Księga, do powstania której przyczyniło się tak wielu wyśmienitych przedstawicieli nauk prawnych.

Kończąc, pozwolę sobie zacytować słowa Profesor Sławomiry Wronkowskiej, która na s. 55 Księgi stwierdza: „Niezależnie [...] od tego, jak postrzega się rolę legislatora, jest on we współczesnym państwie i jego bardzo rozbudowanym prawodawstwie nieodzowny. Obok innych podmiotów uczestniczących w procesie prawotwórczym (polityków, ekspertów, lobbystów) współdecyduje o jakości efektu tego procesu, jakim jest akt normatywny i system prawa, który przez kolejne akty prawotwórcze jest kształtowany".

Łukasz Buczkowski

Państwowa Wyższa Szkoła Informatyki i Przedsiębiorczości w Łomży 